\title{
Assessment of Thyroid Nodules in Children: A Single
}

\section{Center Experience}

\author{
Eda Çelebi Bitkin ${ }^{*}$, Serap Karaman ${ }^{2}$, Murat Başaranoğlu ${ }^{2}$ \\ ${ }^{1}$ Department of Pediatric Endocrinology, V an Yüzüncü Yıl University, Van, Turkey \\ ${ }^{2}$ Department of Pediatrics, Van Yüzüncü Yal University, Van, Turkey
}

\begin{abstract}
Thyroid nodules in children are less common than adults, but with a higher risk of malignancy, metastasis and recurrence. Therefore, detection, follow-up and treatment of thyroid nodules in children is very important. Our study retrospectively analyzed the demographic features, concomitant diseases and ultrasonography (USG) findings of thyroid nodules in children and aimed to obtain information about incidence of malignancy.

We retrospectively analyzed the clinical, laboratory, thyroid USG, Fine needle aspiration biopsy (FNAB) and surgical results of 45 pediatric patients with thyroid nodules.

Forty-five patients were included in the study, female domination was present, and most of the patients were adolescents. Six $(13.3 \%)$ of the patients had a family history of thyroid cancer, and one had a history of radiation. Thyroid-related disease was present in $53.3 \%$ of the patients. Five patients had non-thyroid disease. Thyroid function tests were within normal limits in $33(73.3 \%)$ of the patients. In our patients with pediatric thyroid nodules, FNAB was underwent in $46.6 \%$ according to the nodule size, and malignancy was detected in $2.2 \%$ of our patient group.

Careful evaluation of thyroid nodules that are rarely seen in adults but higher in malignancy than adults should be evaluated. Diagnostic research for thyroid cancer is mostly done in adult patients, our study contributes to the assessment of risk conditions in thyroid nodules in children.
\end{abstract}

Key Words: Thyroid nodule, thyroid carcinoma, thyroid disease

\section{Introduction}

Thyroid nodules are rarely seen in children. However pediatric thyroid nodules have a higher malignancy rate, metastasis and recurrence risk as compared to the thyroid nodules in adults (1). This condition requires evaluating the children and adolescents with thyroid nodules in detail. Thyroid nodules are separate lesions than thyroid tissue. Palpable and incidental thyroid nodules carry the same risk for thyroid cancer. The studies investigating the prediction methods for thyroid cancer were mostly conducted with adults $(2,3)$. On the other hand, the studies in pediatric population are relatively insufficient. In the present study, we retrospectively analyzed the clinical features, laboratory data and thyroid ultrasonography (USG) findings, and also the results of fine needle aspiration biopsy (FNAB) and surgical outcomes in children under 18 years of age and aimed to detect the incidence of thyroid cancer.

\section{Material and Methods}

A total of 45 patients below 18 years of age who were admitted to Pediatric Endocrinology Outpatient Clinic between October 2018 and January 2020 were analyzed retrospectively. Age, gender, body mass index (BMI), presence of clinical symptoms, thyroid staging on physical examination (according to goiter staging of World Health Organization), family history of thyroid cancer, history of radiation exposure, thyroid function tests (TFT) including free T4 and thyroid stimulating hormone (TSH) at the time of diagnosis were evaluated. Free T4 (fT4), TSH, serum anti-thyroglobulin $(\mathrm{Tg})$ antibodies and antithyroid peroxidase (TPO) antibodies were measured with chemi-luminescence immune analysis method by using Abbott Ci 16200 system. Ultrasonography results with regard to thyroid size and nodule characteristics, presence of thyroid disorder or non-thyroid disorders, pathology results of the patients who underwent FNAB (indications: nodule size $>10 \mathrm{~mm}$, solid nodule, microcalcification, history of

\footnotetext{
*Corresponding Author: Eda Çelebi Bitkin, Van Yüzüncü Yıl University Faculty of Medicine Department of Pediatrics, Division of Pediatric Endocrinology, Van, Turkey

E-mail: edacelebitkin@gmail.com, Telephone: +90 (530) 7642406 ,Fax: +90 (432) 4865413
}

ORCID ID: Eda Çelebi Bitkin: 0000-0002-6586-7305, Serap Karaman: 0000-0003-1216-0012, Murat Başaranoğlu: 0000-0003-4408-7075 Received: 16.04.2020, Accepted: 07.07.2020 
radiotherapy) and who underwent thyroid surgery were evaluated retrospectively. Approval for this study was obtained from the Local Ethical Committee (Approval number:2020/03-07).

Statistical Analysis

Descriptive statistics for continuous variables are expressed as mean, standard deviation, minimum and maximum values, while for categorical variables, they are expressed as numbers and percentages. SPSS statistical software was used for calculations.

\section{Results}

A total of 45 patients were included in the study. Mean age of the patients was 12.8 years, and 38 $(84.4 \%)$ were girls and $7(15.6 \%)$ were boys. Clinical symptoms at the time of first admission included swelling in the neck in 18 patients (40\%) (difficulty to swallow in 2 of these patients) and remaining $27(60 \%)$ were asymptomatic. Thyroid was non-palpable in 28 patients $(62.2 \%)$, stage 1 palpable in $2(4.4 \%)$ and stage 2 and stage 3 palpable in $15(33.3 \%)$. There was the family history of thyroid cancer in 6 patients $(13.3 \%)$. History of radiation was detected in one patient who was receiving radio-therapy for nonHodgkin's lymphoma (NHL). Twenty four $(53.3 \%)$ patients had thyroid disorders [congenital hypothyroidism $(\mathrm{CH})$ in 12, Hashimoto's thyroiditis (HT) in 7, Graves disease (GD) in 1, multi-nodular goiter (MNG) in 2, subclinical hypothyroidism in 1 and Pendred syndrome in 1 patient] and there was no thyroid disorders in 19 patients $(42.2 \%)$. When non-thyroid disorders were analyzed, hearing loss was detected in 1 patient with Pendred syndrome, NHL was detected in 1 patient, ectopic kidney in 1 patient, type 1 diabetes mellitus (DM) in 1 patient (the same patient had also HT) and xeroderma pigmentosum in 1 patient (Table 1).

Ultrasonography findings included hypoechoic nodule (11 patients), hypoechoic cyst and nodule (3 patient), isoechoic nodule (6 patients), isoechoic and cystic nodule (4 patients), cystic nodule (20 patients) and micro-calcification (1 patient).

Of the patients, 21 had undergone FNAB. Results of FNAB were benign in 15 patients, 2 had lymphoid hyperplasia, 1 had atypia with unknown significance and 3 had suspected papillary carcinoma. Five patients had undergone surgery. Demographic and clinical characteristics and pathology results of the patients who underwent surgery are presented in Table 2 .

Thyroid function test results were within normal ranges in $33(73.3 \%)$ patients, 1 patient had subclinical hypothyroidism, 11 had evident hypothyroidism and they were receiving therapy. Anti-TPO and anti-Tg antibodies were positive in Hashimoto and Graves diseases. Calcitonin and thyroglobulin values were within normal ranges in all patients.

\section{Discussion}

In the present study, we retrospectively analyzed clinical, laboratory and USG findings, FNAB and surgical pathology results in children and adolescents who had thyroid nodules at a single center.

Thyroid nodules are rarely seen in children and its prevalence is $0.2-5 \%(4,5)$. On the other hand, some recent studies are available reporting that thyroid nodule and thyroid cancer incidence increase in children $(6,7)$. Most of thyroid nodules are usually benign, however there is a 2-3 fold greater malignancy risk in children or adolescents as compared to adults with the estimated incidence of about $20-25 \%$ in children and $5-0 \%$ in adults (8.9). Besides, risk for lymph node and distant metastasis, and recurrence risk are higher in children (10-12). In our study, 21 out of 45 patients were performed $\mathrm{FNAB}$ and 5 patient underwent surgery due to various reasons and one patient was detected to have follicular carcinoma. Ratio of malignancy was found to be $2.2 \%$ in our study, lower than in literature. This difference may be explained with low number of cases.

Some studies have proposed that adolescents had a higher incidence of thyroid cancer as compared to small children $(6,13)$. In a study of Hodax et al., mean age at the time of diagnosis was 15.6 years in children who were detected to have thyroid cancer (14). Mean age was found to be 13.1 years in the study of Divarc1 E. et al. (15). Mean age was 12.8 at the time of diagnosis of thyroid nodules in our study.

Thyroid cancer was reported to be more prevalent among females $(1,6)$. In our study, $84.4 \%$ of the patients with thyroid nodules were girls. This female preponderance may be explained with estrogen sensitivity $(16,17)$.

Obesity is gradually supported with more studies to be a precipitating factor in development of cancer including thyroid cancer (18). In a study, incidence of papillary thyroid cancer was reported 
Table 1. Demographic and clinical features of patients with thyroid nodules

\begin{tabular}{|c|c|}
\hline Parameters & $\mathrm{n}(\%$ or $\mathrm{SDS})$ \\
\hline Age at diagnosis (male/female) & $11.7 \pm 2.7 / 13.9 \pm 3.5$ \\
\hline Sex (male/female) & $7(\% 15.6) / 38(\% 84.4)$ \\
\hline BMI at diagnosis & $54.6 \pm 33.2$ \\
\hline BMI SDS at diagnosis & $0.19 \pm 1.33$ \\
\hline \multicolumn{2}{|l|}{ Symptom at first visit } \\
\hline Goiter (>grade 1) & $15(33.3 \%)$ \\
\hline Palpable mass & 0 \\
\hline Asymtomatic & $30(66.6 \%)$ \\
\hline Family history $(+)$ & $6(13.3 \%)$ \\
\hline History of radiation exposure & $1(2.2 \%)$ \\
\hline \multicolumn{2}{|l|}{ Thyroid Disease } \\
\hline Graves Disease & 1 \\
\hline Hashimoto's thyroiditis & 7 \\
\hline Congenital Hypothyroidism & 12 \\
\hline Multi-nodular Goiter & 2 \\
\hline Subclinical Hypothyroidism & 1 \\
\hline Pendred Syndrome & 1 \\
\hline \multicolumn{2}{|l|}{ Non-thyroid Disorders } \\
\hline Hearing Loss & 1 \\
\hline Non-Hodgkin's Lymphoma & 1 \\
\hline Ectopic Kidney & 1 \\
\hline Type 1 Diabetes Mellitus & 1 \\
\hline Xeroderma Pigmentosum & 1 \\
\hline \multicolumn{2}{|l|}{ Results of FNAB } \\
\hline Benign & 15 \\
\hline Atypia with Unknown Significance & 1 (Right Lobectomy) \\
\hline Lymphoid hyperplasia & 2 \\
\hline Suspected Papillary Carcinoma & 3 (Total Thyroidectomy) \\
\hline
\end{tabular}

\section{SDS: Standard Deviation Scores}

BMI: Body Mass Index

FNAB: Fine Needle Aspiration Biopsy

to increase with increasing BMI (19). However this correlation was not clearly proven in children and adolescents. In our study, BMI was $85 \%$ and above in 11 patients (24.4\%). Body mass index was within normal ranges in our patient who was detected to have follicular carcinoma. For this reason, we could not evaluate the relationship between obesity and thyroid cancer.

Thyroid function test is one of the essential assessment methods for thyroid disorders. Some studies have evaluated TFT in thyroid cancer, tried to predict thyroid cancer and some researchers proposed that serum TSH level increased in thyroid cancer. In some studies conducted in adults, TSH concentration was found to be higher in patients with malignant nodules as compared to the ones with benign nodules $(20,21)$. A clear association could not be shown between TSH and thyroid cancer in the studies carried out with children $(22,23)$. In our study, TSH was within normal ranges in the patient with thyroid cancer however our patient population is not large enough to make a comment about this issue. However we may state that the rate of nodule detection would be higher as more ultrasonographies are done in patients with abnormal TFTs.

In our study, TSH elevation was detected particularly in the patients with Hashimoto's thyroiditis. The relationship between anti-Tg antibody and anti-TPO antibody which are high in HT, and thyroid cancer is still of debate. In previous studies, a relationship was reported between thyroid cancer and HT in children and 
Table 2. Demographic, clinical features and pathology results of patients who underwent surgery due to thyroid nodules

\begin{tabular}{|c|c|c|c|c|c|c|c|c|}
\hline $\begin{array}{c}\text { Patient } \\
\text { no }\end{array}$ & $\begin{array}{l}\text { Age } \\
\text { (years) }\end{array}$ & Gender & $\begin{array}{c}\text { Symptom / } \\
\text { Physical } \\
\text { Exam }\end{array}$ & $\begin{array}{l}\text { Thyroid } \\
\text { Nodule } \\
\text { Size } \\
(\mathrm{mm})\end{array}$ & $\begin{array}{c}\text { USG } \\
\text { Findings }\end{array}$ & $\begin{array}{l}\text { Results of } \\
\text { FNAB }\end{array}$ & Surgery & $\begin{array}{l}\text { Surgical } \\
\text { Pathology }\end{array}$ \\
\hline 1 & 17 & K & $\begin{array}{l}\text { None/Thy } \\
\text { roid } \\
\text { nonpalpabl }\end{array}$ & $18 \times 10$ & $\begin{array}{c}\text { Isoechoi } \\
\text { c }\end{array}$ & $\begin{array}{l}\text { Suspected } \\
\text { Papillary } \\
\text { Carcinoma }\end{array}$ & $\begin{array}{c}\text { Total } \\
\text { Thyroidec } \\
\text { tomy }\end{array}$ & $\begin{array}{l}\text { Follicular } \\
\text { Carcinoma }\end{array}$ \\
\hline 2 & 15.8 & K & $\begin{array}{l}\text { None/Stag } \\
\text { e } 3 \text { goiter }\end{array}$ & $37 \times 25$ & $\begin{array}{l}\text { Isoechoi } \\
\text { c, cystic }\end{array}$ & $\begin{array}{l}\text { Suspected } \\
\text { Papillary } \\
\text { Carcinoma }\end{array}$ & $\begin{array}{l}\text { Total } \\
\text { Thyroidec } \\
\text { tomy }\end{array}$ & $\begin{array}{l}\text { Nodules } \\
\text { Hyperplasia }\end{array}$ \\
\hline 3 & 14.9 & K & $\begin{array}{c}\text { Difficulty } \\
\text { to swallow } \\
\text { / Stage } 3 \\
\text { goiter }\end{array}$ & $40 \times 30$ & $\begin{array}{l}\text { Isoechoi } \\
\text { c, cystic }\end{array}$ & $\begin{array}{l}\text { Suspected } \\
\text { Papillary } \\
\text { Carcinoma }\end{array}$ & $\begin{array}{l}\text { Total } \\
\text { Thyroidec } \\
\text { tomy }\end{array}$ & $\begin{array}{l}\text { Non- } \\
\text { invasive } \\
\text { Follicular } \\
\text { tumor }\end{array}$ \\
\hline 4 & 16 & K & $\begin{array}{l}\text { None/Thy } \\
\text { roid } \\
\text { nonpalpabl } \\
\text { e }\end{array}$ & $11 x 8$ & Cystic & $\begin{array}{l}\text { Atypia with } \\
\text { Unknown } \\
\text { Significance }\end{array}$ & $\begin{array}{c}\text { Right } \\
\text { Lobectom } \\
\text { y }\end{array}$ & $\begin{array}{l}\text { Chronic } \\
\text { Thyroiditis }\end{array}$ \\
\hline 5 & 16 & K & $\begin{array}{c}\text { Difficulty } \\
\text { to swallow } \\
\text { / Stage } 3 \\
\text { goiter }\end{array}$ & $30 \times 26$ & Cystic & Benign & $\begin{array}{c}\text { Right } \\
\text { Lobectom } \\
y\end{array}$ & Benign \\
\hline
\end{tabular}

adolescents. Corrias et al. reported the incidence of thyroid nodules and thyroid cancer as $31.5 \%$ and $3.0 \%$ in patients with auto-immune thyroiditis (23). Keskin et al. investigated the incidence of nodule in children with HT and reported the ratio of thyroid nodule as $13 \%$ and ratio of malignant thyroid cancer as $0.67 \%$ (24). In our study, 7 $(15.5 \%)$ of our patients had HT and malignancy was not detected in these patients.

Echogeneity of thyroid nodules is among the prominent characteristics particularly for hypoechoic nodules that were reported to have a malignant nature $(20,25)$. While most of mixed echoic nodules and cystic nodules are benign, solid nodules were proven to be usually malignant $(25,26)$. In our study, pathology result was benign in 15 patients who were performed FNAB and USG was reported to be cystic in all. The patient who was detected to have malignancy was reported to have an isoechoic nodule.

In our study, in the non-thyroid disorder group, the patient with hearing loss was diagnosed with Pendred syndrome.

Another patient with non-thyroid disease had xeroderma pigmentosum, coexistence of this condition and thyroid cancer/thyroid nodule was not encountered in literature.
Our study has some limitations. First is its retrospective design and thereby the data's having been evaluated by different radiologists and pathologists, and this condition could have resulted in various results. Another limitation is the small number of patients.

In conclusion, we evaluated the management of thyroid nodules in children. $46.6 \%$ of the patients with thyroid nodule underwent FNAB and malignancy ratio was detected to be $2.2 \%$ in the study sample. Female gender was seen to be prominent. Since we have a patient with malignancy, we could not comment on the relationship between risk factors and malignancy. For evaluation of pediatric thyroid nodules, a meticulous physical examination, a comprehensive assessment of radiation history, family history, laboratory tests and most importantly, USG findings are required. Prospective studies conducted with larger patient populations are required for investigating pediatric thyroid nodules.

\section{References}

1. Suh J, Choi HS, Kwon A, Chae HW, Kim HS. Adolescents with thyroid nodules: retrospective analysis of factors predicting malignancy. Eur J Pediatr 2020; 179: 317-325. 
2. Papini E, Guglielmi R, Bianchini A, et al. Risk of malignancy in nonpalpable thyroid nodules: predictive value of ultrasound and colorDoppler features. J Clin Endocrinol Metab 2002; 87: 1941-1946.

3. Kamran SC, Marqusee E, Kim MI, et al. Thyroid nodule size and prediction of cancer. J Clin Endocrinol Metab 2013; 98: 564-570.

4. Kaloumenou I, Alevizaki M, Ladopoulos C, et al. Thyroid volume and echostructure in schoolchildren living in an iodine-replete area: relation to age, pubertal stage, and body mass index. Thyroid 2007; 17: 875-881.

5. Rallison ML, Dobyns BM, Meikle AW, Bishop M, Lyon JL, Stevens W. Natural history of thyroid abnormalities: prevalence, incidence, and regression of thyroid diseases in adolescents and young adults. Am J Med. 1991; 91: 363-370.

6. Hogan AR, Zhuge Y, Perez EA, Koniaris LG, Lew JI, Sola JE. Pediatric thyroid carcinoma: incidence and outcomes in 1753 patients. J Surg Res 2009; 156: 167-172.

7. Vergamini LB, Frazier AL, Abrantes FL, Ribeiro KB, Rodriguez Galindo C. Increase in the incidence of differentiated thyroid carcinoma in children, adolescents, and young adults: a populationbased study. J Pediatr 2014; 164: 1481-1485.

8. Gupta A, Ly S, Castroneves LA, et al. A standardized assessment of thyroid nodules in children confirms higher cancer prevalence than in adults. J Clin Endocrinol Metab 2013; 98: 3238-3245.

9. Niedziela M. Pathogenesis, diagnosis and management of thyroid nodules in children. Endocr Relat Cancer 2006; 13: 427-453.

10. Feinmesser R, Lubin E, Segal K, Noyek A. Carcinoma of the thyroid in children-a review. J Pediatr Endocrinol Metab 1997; 10: 561-568.

11. Josefson J, Zimmerman D. Thyroid nodules and cancers in children. Pediatr Endocrinol Rev 2008; 6: 14-23.

12. O'Gorman CS, Hamilton J, Rachmiel M, Gupta A, Ngan BY, Daneman D. Thyroid cancer in childhood: a retrospective review of childhood course. Thyroid. 2010; 20: 375-380.

13. Francis GL, Waguespack SG, Bauer AJ et al. American Thyroid Association Guidelines Task Force. Management guidelines for children with thyroid nodules and differentiated thyroid cancer. Thyroid 2015; 25: 716-759.

14. Hodax JK, Bowerman K, Quintos JB. Benign thyroid nodules in pediatric patients: determining best practices for repeat ultrasound evaluations.J Pediatr Endocrinol Metab 2019; 32: 895-901.
15. Divarc1 E, Çeltik Ü, Dökümcü Z. et al. Management of Childhood Thyroid Nodules: Surgical and Endocrinological Findings in a Large Group of Cases. J Clin Res Pediatr Endocrinol 2017; 9: 222-228.

16. Derwahl M, Nicula D.Estrogen and its role in thyroid cancer. Endocr Relat Cancer 2014; 21: 273-283.

17. Vannucchi G, De Leo S, Perrino M. et al. Impact of estrogen and progesterone receptor expression on the clinical and molecular features of papillary thyroid cancer. Eur J Endocrinol 2015; 173: 29-36.

18. Kitahara CM, Platz EA, Freeman LE, et al. Obesity and thyroid cancer risk among U.S. men and women: a pooled analysis of five prospective studies. Cancer Epidemiol Biomarkers Prev 2011; 20: 464-472.

19. Wu C, Wang L, Chen W, Zou S, Yang A. Associations between body mass index and lymph node metastases of patients with papillary thyroid cancer: A retrospective study. Medicine (Baltimore) 2017; 96: e6202.

20. Mussa A, De Andrea M, Motta M, Mormile A, Palestini N, Corrias A. Predictors of malignancy in children with thyroid nodules. J Pediatr 2015; 167: 886-892.e881.

21. Papendieck P, Gruneiro-Papendieck L, Venara $M$ et al. Differentiated thyroid cancer in children: prevalence and predictors in a large cohort with thyroid nodules followed prospectively. J Pediatri 2015; 167: 199-201.

22. Corrias A, Einaudi S, Chiorboli E, Weber G, Crinò A, Andreo M. et al. Accuracy of fine needle aspiration biopsy of thyroid nodules in detecting malignancy in childhood: comparison with conventional clinical, laboratory, and imaging approaches. J Clin Endocrinol Metab 2001; 86: 4644-4648.

23. Corrias A, Cassio A, Weber G, Mussa A, Wasniewska M, Rapa A. et al. Thyroid nodules and cancer in children and adolescents affected by autoimmune thyroiditis. Arch Pediatr Adolesc Med 2008; 162: 526-531.

24. Keskin M, Savas-Erdeve S, Aycan Z. Coexistence of thyroid nodule and thyroid cancer in children and adolescents with hashimoto thyroiditis: a single-center study. Horm Res Paediatr 2016; 85: 181-187.

25. Al Nofal A, Gionfriddo MR, Javed A. et al. Accuracy of thyroid nodule sonography for the detection of thyroid cancer in children: systematic review and meta-analysis. Clin Endocrinol 2016; 84: 423-430.

26. Moon WJ, Jung SL, Lee JH. et al. Benign and malignant thyroid nodules: US differentiationmulticenter retrospective study. Radiology 2008; 247: 762-770. 